\title{
Notes on the Egg Bearing Cyclopoid Copepod, Oithona similis Claus, 1866 of the Arabian Sea
}

\author{
Jean J. JOSE ${ }^{1 *}$, Appukuttan CHANDRAN², Lincy ALEX ${ }^{3}$, Aaron P. LIPTON ${ }^{4}$ \\ ${ }^{1}$ MES Ponnani College, Department of PG and Research Centre in Aquaculture \& Fishery Microbiology, Malappuram - 679586, Kerala, \\ India; jeanlincy@gmail.com (*correspondingauthor) \\ ${ }^{2}$ University College of Applied Life Sciences, Mahatma Gandhi University Regional Centre, Pathanamthitta-689645, Kerala, India \\ ${ }^{3}$ St. Gregorios College, Department of Zoology, Kottarakkara-691531, Kerala, India \\ ${ }^{4}$ Central Marine Fisheries Research Institute, Marine Biotechnology Laboratory, Vizhinjam-695 521, Kerala, India
}

\begin{abstract}
Morphology of the marine egg bearing cyclopoid copepod Oithona similis occurring along the southwest coast of India

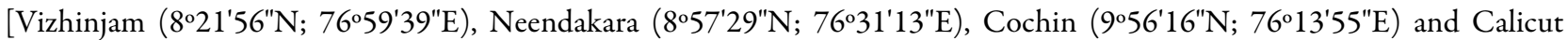
$\left.\left(11^{\circ} 13^{\prime} 33^{\prime \prime} \mathrm{N} ; 75^{\circ} 46^{\prime} 30^{\prime \prime} \mathrm{E}\right)\right]$ from January to December 2010 at different seasons (pre monsoon, monsoon and post monsoon) were studied. Detailed comparison of the structure of different appendages of $O$. similis with those already available for the species from Norway, Japan, China, Spain and Russia revealed minute differences in the armature of appendages, number and arrangement of spines, setae of swimming legs and anal laminae. The total length of the specimen collected from all the four stations in the study ranged from 615 to $650 \mu$. The smallest specimens were obtained from Calicut.
\end{abstract}

Keywords: Arabian sea, identification, morphology, Oithona similis

\section{Introduction}

Copepods belonging to the class Maxillopoda, are small but extremely abundant crustaceans which occur in every type of aquatic habitat (Razouls et al., 2011). They are amazingly diverse in body form and mode of life ranging from free-living and associated forms to ecto, meso and endo-parasitic forms. It constitutes one of the greatest parts of the Metazoa comprising nearly 11500 species (Bowman and Abele, 1982) of which approximately 2300 are marine planktonic species (Razouls et al., 2011). Cyclopoid copepods of the family Oithonidae are cyclically abundant members of the planktonic fauna of many temperate and tropical estuaries and embayments (Ferrari and Orsi, 1984), and form a dominant copepod species in coastal and oceanic ecosystems (Roman et al., 1985; Paffenhofer et al., 1987). Even though much has been studied and published about plankton communities and planktonic copepods of estuaries and backwaters of India, very few attempts have been made to study the availability, nature of abundance, distribution and life of oithonid copepods inhabiting the coastal waters of India. In spite of the fact that they form an integral part of the pelagic food web, oithonids occurring along the southwest coast of India have not been given the right attention they certainly deserve. An exception to this is the work of Kasturirangan (1963) who dealt with the taxonomy of this group along with those of other planktonic copepods of India. In view of the present paucity of information relating to the biology of oithonidae of the Indian region, we studied the morphological characteristics of the most abundant species of Oithona namely, $O$. similis distributed along the south west coast of India.

\section{Materials and methods}

\section{Field sampling and Study area}

Zooplankton samples were collected from four stations (Fig. 1) viz., Vizhinjam (8²1'56"N; 7659'39"E), Neendakara $\quad\left(8^{\circ} 57^{\prime} 29^{\prime \prime N}\right.$; 76031'13"E), Cochin (9०56'16"N; 76 $16^{\prime} 55^{\prime \prime} \mathrm{E}$ ) and Calicut (CLT) $\left(11^{\circ} 13^{\prime} 33^{\prime \prime} \mathrm{N} ; 75^{\circ} 46^{\prime} 30^{\prime \prime} \mathrm{E}\right)$ distributed along southwest coast of India by horizontal hauling using a bongo net (mouth diameter $40 \mathrm{~cm}$, mesh size: $60 \mu \mathrm{m}$ ) equipped with a calibrated flow meter (General Oceanics, Model-2030). The net was operated from the deck of the fishing vessel for 10 minutes at a hauling speed of 2 knots/hour. These sampling stations were selected on the basis of high productivity, hydrological variation, zooplankton assemblages and abundance of copepods as understood from the previous four year's data on coastal pollution monitoring survey conducted at $0.5,1.0,3.0,5.0$ and 10.0 $\mathrm{km}$ distance from shore region along southwest coast of India extending from Vizhinjam to Karwar. 


\section{Sampling protocol}

After each collection, the cyclopoid copepod, $O$. similis were sorted using a dissection microscope after arresting their movement using chilled seawater on board and the samples were fixed in $4.0 \%$ formaldehyde buffered with sodium tetra borate. The identification of the specimens was confirmed as per the description given by Claus (1866) and Kasturirangan (1963) on the basis of the following characteristics; little large genital segment than the urosome length, maxillipeds and $2^{\text {nd }}$ maxillae slender, covered with numerous spiny bristles for genus Oithona. Species confirmation was based on the $1^{\text {st }}$ antennae twice geneticulate, the $1^{\text {st }}$ segment beyond the proximal elbow; outer marginal spines are 2 , 2, 2, 2, internal exopod segments I to 4; length 0.5 to 0.7 $\mathrm{mm}$.

The intact specimens selected for morphological studies were cleared in a dilute solution of lactic acid and the appendages were carefully dissected out using a fine mounted needle under a stereoscope microscope (Labomed CSM 2). For the purpose, 10 adult specimens including male and females carrying eggs were pooled from the entire collection of each transect. Drawings were made with the aid of a Camera Lucida (prism type).

\section{Results and discussion}

The body of the species was rather slender, with an abruptly blunt or rounded head. In lateral view the head was bent ventrally in to a sharply pointed rostrum not visible dorsally. Morphometry of $O$. similis from different stations distributed along south west coast of India showed no differences. The total length of the specimen collected from all the four stations in the present study ranged from 615 to $650 \mu$ (Tab. 1) and the smallest adult size group $(<650 \mu)$ was noted at Calicut. The prosome of the species was elongate, oval and nearly $2 \frac{1}{2}$ times as long as wide, the greatest width being noted at the posterior end of the cephalosome at the region of the anterior margin of the $1^{\text {st }}$ pedigerous segment. In lateral view, the pedigerous somites 1 and 2 were about the same width, but the pedigerous segments 3 and 4 gradually narrowed with rounded corners. The urosome was narrow ranging in length from 200 to $233 \mu$. The first two abdominal segments were of the same size. The anal segment was slightly broader than long. The anal laminae were simple nearly 2 to $2 \frac{1}{2}$ times longer than broad. The genital segment was nearly rectangular and slightly swollen laterally towards the anterior end.

Egg sacs were oblong extending from the genital segment up to the proximal end of the anal lamina. The length of the egg sacs varied from 150 to $160 \mu$ with a width of about 50 to $60 \mu$. The diameter of the eggs varied from 35 to $52 \mu$ (Fig. 2).

First antennae were long (200 to 266 $\mu$ ) and slender with 11 segments (Fig. 2). When folded laterally, the tip of the antennae reached the middle region of the $3^{\mathrm{rd}}$ pedigerous somite. Second antennae (Fig. 3a) were three segmented. The basis was provided with one dorsomedial seta. The endopod I had one medial seta at mid length. Endopod II with one medial seta and four dorsomedial setae. One of the setae was much elongated than the others. The endopod III was with seven setae at the tip, two of the epical setae were long nearly three to four times the length of the distal segment. Exopod was absent.

The mandible consisted of a gnathobase and a palp.

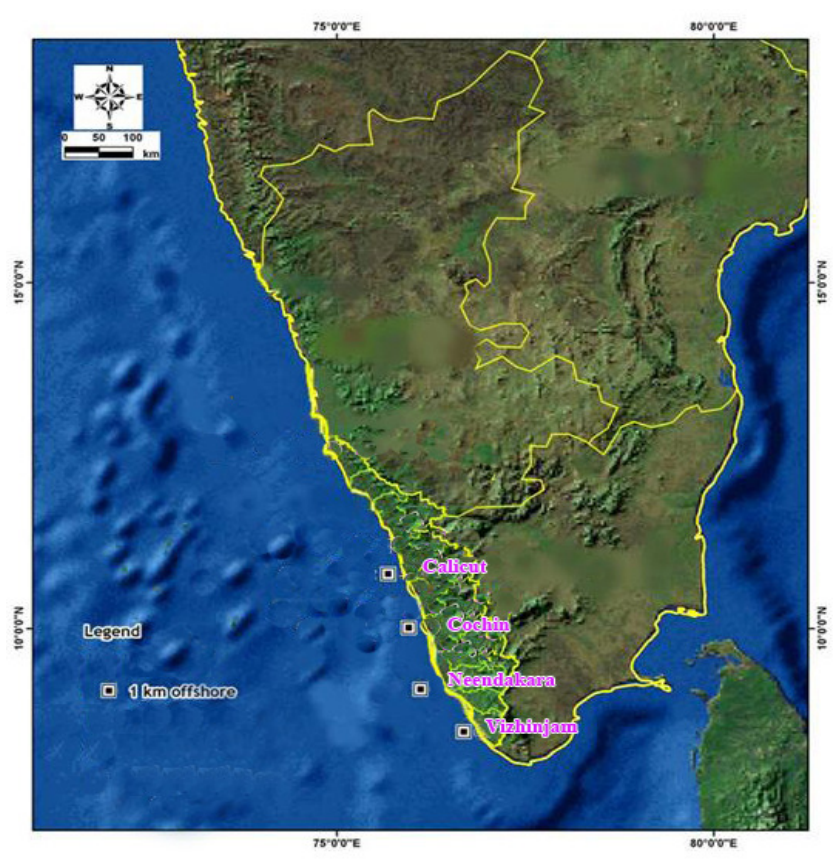

Fig. 1. Area of investigation along southwest coast of India

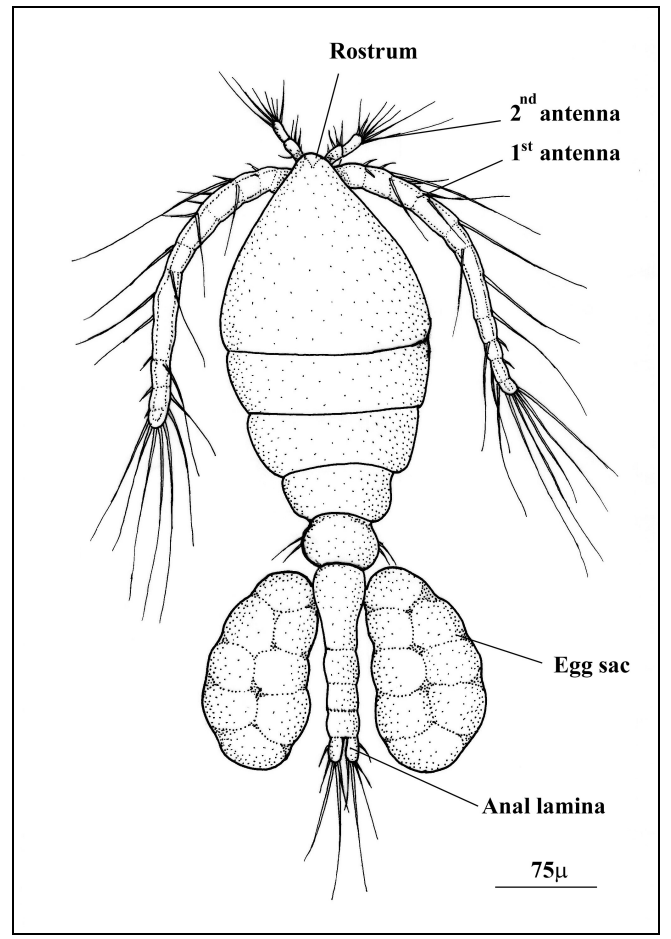

Fig. 2. Dorsal view of Oithona similis female

The mandibular palp consisted of basis, one segmented endopod and four segmented exopod. Basis was provided with one medial seta and with two thick slightly curved spines with marginal spinules. The $1^{\text {st }}$ maxilla (Fig. 3b) 
33

with inner lobe having nine spines, basipod II was with one seta. Exopod with one segment fused to basipod and with four short setae. Second maxilla consisted of syncoxa with two endites, a precoxal endite and a coxal endite with one seta. Basis with two endites each with three short setae. Endopod four segmented. Endopod I with a claw like seta at base. Endopod II with four setae, III with two seta and IV with two long and two short setae. Maxilliped (Fig. 3c) with precoxa of two lobes, proximal with one seta and distal with three setae. Coxal lobe was provided with two setae. The basis was elongate with two setae and medial denticles. Endopod was two segmented. The first segment was provided with three setae, one of which is rather elongate. The second segment of the endopod was with two long and one short seta.

Swimming legs 1 to 4 were biramous with one outer marginal seta on $2^{\text {nd }}$ basal segment. Endopod and exopod of $1^{\text {st }}$ to $4^{\text {th }}$ swimming legs were three segmented (Fig. $3 \mathrm{~d})$. The external spines of all the exopod of legs were ornamented on both sides and were provided with a hyaline membrane, often reduced, whose outer edge was serrate. The epical spines of the exopod of all legs were distinctly thickened, rigid structure with a well developed serrate hyaline membrane on its lateral edge. The details of total number and arrangement of spines and setae on the exopod and endopod of legs 1 to 4 are presented in Tab. 2. The anal lamina (Fig. 3e) had two long epical setae and two shorter ones on the posterolateral corners. Other short setae were present on the median margin of anal lamina. The long epical setae were thicker than the others, the inner one being roughly $2 \frac{1}{2}$ times longer than the outer. A detailed study on the morphology of the common species of $O$. similis occurring along the southwest coast of India revealed no marked differences in important morphological features of the specimens collected from different stations. Nevertheless, a detailed comparison of the structure of different appendages of $O$. similis collected from the present areas with those already available for the species from other geographical areas revealed minute differences in the armature of appendages, number and arrangement of spines, setae of swimming legs and anal laminae.

Tab. 1. Morphometric measurements $(\mu \mathrm{m})$ of Oithona similis collected from the different stations along the southwest coast of India

\begin{tabular}{|cccccc}
\hline Sl. No & $\begin{array}{c}\text { Oithona similis (Claus, 1866) } \\
\text { Morphometry }(\mu \mathrm{m}), \mathrm{n}=10\end{array}$ & Vizhinjam & Neendakara & Cochin & Calicut \\
\hline 1 & Total length & 650.13 & 650.13 & 650.13 & 616.80 \\
\hline 2 & Cephalosome length & 166.70 & 183.40 & 183.40 & 183.40 \\
\hline 3 & Cephalosome width & 150.03 & 166.70 & 150.03 & 150.03 \\
\hline 4 & Metasome length & 250.05 & 250.05 & 250.05 & 233.38 \\
\hline 5 & Urosome length & 233.38 & 216.71 & 216.71 & 200.04 \\
\hline 6 & Caudal setae outer length & 141.70 & 150.03 & 141.70 & 150.03 \\
\hline 7 & Caudal setae inner length & 216.71 & 200.04 & 200.04 & 200.04 \\
\hline 8 & Antennae length & 250.05 & 266.72 & 250.05 & 200.05 \\
\hline 9 & Anal segment length & 30.80 & 30.80 & 30.80 & 30.80 \\
\hline 10 & Anal segment width & 39.60 & 37.40 & 37.40 & 35.20 \\
\hline 11 & Anal laminae length & 39.60 & 44.00 & 39.60 & 39.60 \\
\hline 12 & Anal laminae width & 17.60 & 15.04 & 17.60 & 13.20 \\
\hline
\end{tabular}

Tab. 2. Setal formula of the exopod (outer and inner margins) and endopod of the four legs ( $\mathrm{P}_{1}$ to $\left.\mathrm{P}_{4}\right)$ of female Oithona similis recorded by various authors from different geographical areas

\begin{tabular}{|c|c|c|c|c|c|c|c|c|c|c|c|c|}
\hline \multicolumn{3}{|c|}{$\mathrm{P}_{1}$} & \multicolumn{3}{|c|}{$\mathrm{P}_{2}$} & \multicolumn{3}{|c|}{$\mathrm{P}_{3}$} & \multicolumn{3}{|c|}{$\mathrm{P}_{4}$} & \multirow{3}{*}{ References } \\
\hline \multicolumn{2}{|c|}{ Exopod } & \multirow{2}{*}{$\begin{array}{l}\text { Endopod } \\
\text { Setae }\end{array}$} & \multicolumn{2}{|c|}{ Exopod } & \multirow{2}{*}{$\begin{array}{l}\text { Endopod } \\
\text { Setae }\end{array}$} & \multicolumn{2}{|c|}{ Exopod } & \multirow{2}{*}{$\begin{array}{c}\text { Endopod } \\
\text { Setae }\end{array}$} & \multicolumn{2}{|c|}{ Exopod } & \multirow{2}{*}{$\begin{array}{c}\text { Endopod } \\
\text { Setae }\end{array}$} & \\
\hline Spines & Setae & & Spines & Setae & & Spines & Setae & & Spines & Setae & & \\
\hline I, I, II & $0,1,4$ & - & $\mathrm{I}, 0, \mathrm{I}$ & $0,1,5$ & - & $\mathrm{I}, 0, \mathrm{I}$ & $0,1,5$ & - & $0,0,0$ & $0,1,5$ & - & Giesbrecht, 1892 \\
\hline I, I, II & $0,1,4$ & $1,1,6$ & $\mathrm{I}, 0, \mathrm{I}$ & $0,1,5$ & $1,2,6$ & - & - & - & $0,0,0$ & $0,1,5$ & $1,2,5$ & Sars, 1913 \\
\hline I, I, II & $0,1,4$ & $1,1,6$ & I, 0, I & $0,1,5$ & $1,2,6$ & $\mathrm{I}, 0, \mathrm{I}$ & $0,1,5$ & $1,2,6$ & $0,0,0$ & $0,1,5$ & $1,2,5$ & $\begin{array}{l}\text { Shen and Bai, } \\
1956\end{array}$ \\
\hline I, I, II & $0,1,4$ & $1,1,6$ & I, I, II & $0,1,5$ & $1,2,6$ & I, I, II & $0,1,5$ & $1,2,6$ & I, I, II & $0,1,5$ & $1,2,5$ & Mori, 1964 \\
\hline I, I, II & $0,1,4$ & $1,1,6$ & I, 0, II & $0,1,5$ & -- & $\mathrm{I}, 0, \mathrm{I}$ & $0,1,5$ & $1,2,6$ & - & - & - & Shuvalov, 1980 \\
\hline I, I, II & $0,1,4$ & $1,1,6$ & I, I, III & $0,1,5$ & $1,2,5$ & $\mathrm{I}, 0, \mathrm{I}$ & $0,1,5$ & $1,2,6$ & $0,0,0$ & $0,1,5$ & $1,2,5$ & Nishida, 1985 \\
\hline I, I, II & $0,1,4$ & $1,1,6$ & $\mathrm{I}, 0, \mathrm{I}$ & $0,1,5$ & $1,2,6$ & $\mathrm{I}, 0, \mathrm{I}$ & $0,1,5$ & $1,2,6$ & $0,0, \mathrm{I}$ & $0,1,5$ & $1,2,5$ & $\begin{array}{c}\text { Mazzochi et al., } \\
1995\end{array}$ \\
\hline I, I, II & $0,1,4$ & $1,1,6$ & I, I, III & $0,1,5$ & $1,2,6$ & $\mathrm{I}, 0, \mathrm{I}$ & $0,1,5$ & $1,2,6$ & $0,0,0$ & $0,1,5$ & $1,2,5$ & $\begin{array}{c}\text { Razouls et al., } \\
2011\end{array}$ \\
\hline I, I, II & $0,1,4$ & - & $\mathrm{I}, 0, \mathrm{I}$ & $0,1,5$ & - & $\mathrm{I}, 0, \mathrm{I}$ & $0,1,5$ & - & $0,0, \mathrm{I}$ & $0,1,5$ & - & $\begin{array}{c}\text { Vives and } \\
\text { Shemeleva, } 2010\end{array}$ \\
\hline I, I, II & $0,1,4$ & $1,1,6$ & I, I, III & $0,1,5$ & $1,2,6$ & I, I, II & $0,1,5$ & $1,2,6$ & I, I, II & $0,1,5$ & $1,2,5$ & Present work \\
\hline
\end{tabular}


The rostrum of the present species described resembled that of $O$. decepiens, $O$. fallax and $O$. fragilis. The other rostrate species of Oithona include: $O$. robusta, $O$. brevicornis, $O$. aurensis and $O$. wellerhausi (Nishida and Ferrari, 1983). Unlike the O. wellerhausi species (Nishida, 1979) in the present species, there is no swelling at the base of rostrum similar to the condition observed in O. decepiens and O. fallax (Giesbrecht, 1892). But for subtle differences in the setation, the structure of $1^{\text {st }}$ and $2^{\text {nd }}$ antennae, mandible, $1^{\text {st }}$ and $2^{\text {nd }}$ maxilla and maxilliped of the present species of $O$. simils was more or less comparable to those previously described by Sars (1913), Nishida (1985) and Razoulus et al. (2007). However, notable differences were noticed in the structure and setation of the swimming legs of $O$. similis. According to Ferrari and Bowman (1980), one of the important characters traditionally used to differentiate species within the family Oithonidae include the number of setae and spines on the exopod of swimming legs 1 to 4. The setal formulae of the exopod and endopod of $O$. similis recorded from the different geographical areas presented in Tab. 2 could indicate that the formula of the exopod and endopod of the $1^{\text {st }}$ leg of the present species conform closely to that already recorded for the species, whereas in the case of leg 2, the setal formulae of the present species are comparable only to those recorded by Nishida (1985) and Razoulus et al. (2007). In the case of leg 3 of the present specimens, while the setal formula of exopod and endopod are more or less comparable to those reported by the previous workers, the spines of the

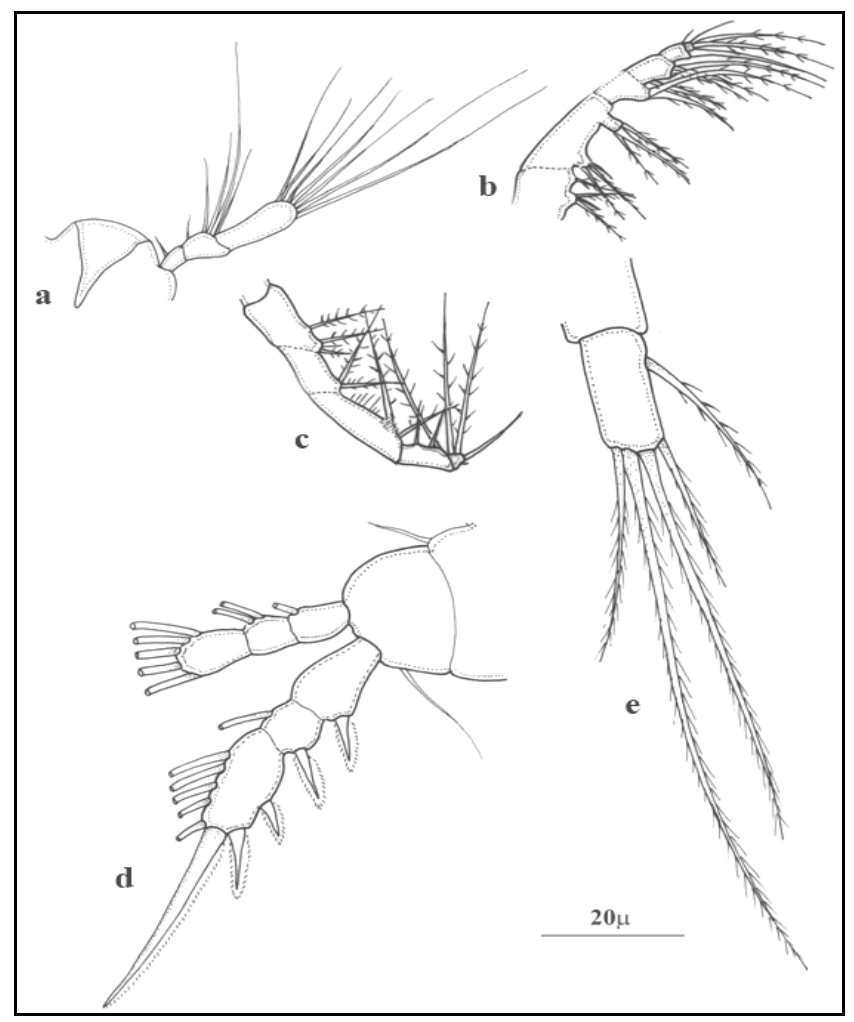

Fig. 3. Morphological characters of Oithona similis

a. $2^{\text {nd }}$ antenna; b. maxilla; c. maxilliped; d. swimming leg; e. anal lamina[b \& c modified from S. Nishida in Bull. Ocean Res. Inst., Univ. Tokyo, 1985, No 20 (p.90, Fig.51)] exopod are I, I and III as against I, I and II (Mori, 1964) and I, 0 and I reported by other authors (Tab. 2). A similar condition was noted in the case of swimming legs 4 (P 4) were the exopod spine formula is I, I and II similar to that recorded by Mori (1964). The majority of the other authors reported no spines on the exopod of $\mathrm{P}$ 4 (Tab. 2).

The other noticeable feature in the morphology of $O$. similis described included the spination of the anal lamina. The setation and structure of anal lamina was very much comparable to that of Limnoithona sinensis and $O$. davisae reported by Ferrari and Orsi (1984).

Oithona similis is a cosmopolitan species, widespread in the world ocean (Nielsen and Sabatini, 1996). Since the first description of the species in 1866 by Claus, considerable amount of data have accumulated mainly on different aspects relating to the biology, distribution, morphology and molecular biology of the species (Sabatini and Kiorboe, 1994; Nielsen and Sabatini, 1996; Ferrari and Ivanenko, 2001 and Cepeda et al., 2012). From the Indian region, observations on the distribution of species of Oithona are scarce being limited to the works of Madhupratap (1999) and Jean et al. (2012).

These results therefore indicate an apparent paucity of information on Oithonidae in Indian waters. It is thus highly essential to initiate comprehensive studies involving the taxonomy, biology and distribution of the abundant Oithonid group of copepod along the Indian coasts.

\section{Acknowledgements}

We are grateful for the assistance in the field from the Masters and Crew members of fishing crafts. This paper is a part of the $\mathrm{PhD}$ thesis work of corresponding author registered in Manonmaniam Sundaranar University, India.

\section{References}

Bowman T, Abele L (1982). Classification of the recent Crustacea, 1-27 p. In: Abele L (Ed.). The biology of Crustacea, Systematics, the fossil record, and biogeography. Academic Press, New York.

Cepeda GD, Bercial LB, Bucklin A, Beron CM, Vin MD (2012). Molecular Systematic of three species of Oithona (Copepoda, Cyclopoida) from the Atlantic Ocean: Comparative Analysis using 28S rDNA. PLoS One, 7:1-7.

Claus C (1866). Die Copepoden-Fauna von Nizza. Eing Beitrag zur Charakteristik der Formen und deren Abanderungen "im Sinne Darwin's". Schr. Gex. Beford. Ges. Naturw. Marburg, suppl., 1:1-34.

Ferrari FD, Bowman TE (1980). Pelagic copepods of the family Oithonidae (Cyclopoida) from the east coasts of Central and South America. Smithsonian Contribut Zool 312:27.Ferrari FD, Ivanenko VN (2001). Interpreting segment homologies of the maxilliped of cyclopoid copepods by comparing stagespecific changes during development. Org Div Evol 1:113131.

Ferrari FD, Orsi J (1984). Oithona davisae, new species, and Limnoithona sinensis (Burckhardt, 1912) (Copepoda: 
Oithonidae) from the Sacramento-San Joaquin Estuary, California. J Crust Biol 4:106-126.

Giesbrecht W (1892). Systematik und faunistik der pelagishen Copepoden des Golfes von Neapel. Fauna und Flora des Golfes von Neapel und der angrenzenden Meeresabschnitte 19:1-831.

Jean JJ, Lipton AP, Lincy Alex, Udayakumar P, Rajesh BR Miranda MTP (2012). Observation on Marine Copepod Appendicularian Naturally Changing Concentrations along Southwest Coast of India. Not Sci Biol 4(4):20-26.

Kasturirangan LR (1963). Key to the identification of the more common pelagic copepods of the Indian coastal waters. INCOR, C S I R Publications 2, New Delhi 128 p.

Madhupratap M (1999). Free-living copepods of the Arabian Sea: Distributions and research perspectives. Ind J Mar Sci 28:146149.

Mazzochi MG, D’Alcala R (1995). Recurrent patterns in zooplankton structure and succession in a viable coastal environment. ICES J Mar Sci 52:679-691.

Mori T (1964). The Pelagic Copepoda from the Neigh-bouring Waters of Japan. The Soyo Company Inc, Tokyo, $150 \mathrm{p}$.

Nielsen TG, Sabatini M (1996). Role of cyclopoid Oithona spp. in North Sea plankton communities. Mar Ecol Prog Ser 139:7993.

Nishida S, Ferrari FD (1983). Redescription of Oithona brevicornis Giesbrecht and O. aruensis Fruchtl, new rank, with notes on the status of O. spinulosa Lindberg. Bull Plank Soc Japan 30:71-80.

Nishida S (1979). A new species of Oithona (Copepoda, Cyclopoida) from the Central Pacific. Bull Nat Sci Mus Ser Zool Tokyo 5:89-93.

Nishida S (1985). Taxonomy and distribution of the family Oithonidae (Copepoda, Cyclopoida) in the Pacific and
Indian Oceans. Bull Ocean Res Inst Univ Tokyo 20:167 p. Paffenhofer GA, Sherman BK, Lee TN (1987). Summer upwelling on the southeastern continental shelf of the U.S.A. during 1981: Abundance, distribution and patch formation of zooplankton. Prog Oceanogr 19:403-436.

Razouls C, de Bove'e F, Kouwenberg J, Desreumaux N (2007). Diversity and Geographic Distribution of Marine Planktonic Copepods. See http://copepodes.obsbanyuls fr/en Accessed on November, 2007.

Razouls C, de Bovee F, Kouwenberg J, Desreumaux N (2011). Diversity and Geographic Distribution of Marine Planktonic Copepods. Available: http://copepodes.obs-banyuls.fr. Accessed 2011 Dec 6.

Roman M, Gauzens A, Cowles T (1985). Temporal and spatial changes in epipelagic microzooplankton and mesozooplankton biomass in warm-core Gulf Stream ring 82B. Deep Sea Res 32:1007-1022.

Sabatini M, Kiorboe T (1994). Egg production, growth and development of the cyclopoid copepod Oithona similis. J Plank Res 16:1329-1351.

Sars GO (1913). Copepoda Cyclopoida. Parts I \& II. Oithonidae, Cyclopinidae, Cyclopidae (part). An Account of the Crustacea of Norway, with short descriptions and figures of all the species, 6, 1-32, pls. 1-16.

Shen CJ, Bai SO (1956). The marine Copepoda from the spawning ground of Pneumatophorus japonicus (Houttuyn) off Chefoo, China. Act Zool Sinica 8:177-234.

Shuvalov VS (1980). Cyclopoid Copepods of Oithonidae family of the World Ocean. Nauka, Leningrad 197 p.

Vives F, Shemeleva AA (2010). Crustacea, Copépodos marinos II. Non Calanoida. In: Fauna Iberica, vol. 33. Ramos (Eds.), Museo Nacional de Ciencias Naturales, CSIC, Madrid, 486 p. 